\section{Evidences of the association between individual attributes and bullying: a cross- sectional study with adolescents from Florianópolis, Santa Catarina State, Brazil}

\author{
Evidências da associação entre atributos \\ individuais e bullying: um estudo transversal \\ em adolescentes de Florianópolis, Santa \\ Catarina, Brasil
}

\section{Evidencias de asociación entre atributos individuales y bullying: un estudio transversal con adolescentes de Florianópolis, Estado de Santa Catarina, Brasil}

Sílvia Letícia Alexius 1

Michel Carlos Mocellin 1

Elizabeth Nappi Corrêa 1

Janaina das Neves 1

Francisco de Assis Guedes de Vasconcelos 1

Arlete Catarina Tittoni Corso 1

doi: 10.1590/0102-311X00118617

\begin{abstract}
This study aimed to estimate the prevalence of bullying and to verify the association between nutritional status, demographic and socioeconomic factors, and individual attributes among schoolchildren aged from 11 to 14 years. This is cross-sectional study with a probabilistic sample of 975 adolescents attending public and private schools in Florianópolis, Santa Catarina State, Brazil. Bullying was investigated with a self-administered questionnaire by applying Item Response Theory and dichotomized according to victimization or not. Body mass index (BMI) was classified according to the World Health Organization criteria. Data such as age, school type and location, household income, as well as the education background of the parents were collected by a questionnaire given to the parents. Crude and adjusted analyses were performed using logistic regression. The prevalence of victims of bullying and of overweight/obese adolescents was $13.2 \%$ and $29 \%$, respectively. No association was found between bullying and age, sex, school type, mother's education, household income, and overweight/obesity. The crude analysis model indicated that overweight/obese adolescents and those with individual attributes (fat thin, tall, short, good-looking, ugly, from a different ethnic background, rich, poor, with a disability and/or other) had a greater chance of being bullied. In the analysis model adjusted by household income and stratified by sex, boys were discriminated for being fat, good-looking, ugly, or for having a disability, while girls were discriminated for being fat, tall, short, ugly, rich, poor, among other individual attributes.
\end{abstract}

Adolescent Behavior; Bullying; Discrimitation; Obesity; Overweight
Correspondence

F. A. G. Vasconcelos

Rua Capitão Romualdo de Barros 997, Bloco 1, apto. 203,

Florianópolis, SC 88040-900, Brasil.

f.vasconcelos@ufsc.br

1 Departamento de Nutrição, Universidade Federal de Santa Catarina, Florianópolis, Brasil. 


\section{Introduction}

Bullying in the school environment has been the central theme of studies in various countries, since this phenomenon can be extremely harmful to the individuals involved, leading to serious medium and long-term social consequences. There is evidence that the discrimination is associated with later onset of physiological stress, as well as psychosis 1,2. Bullying can, therefore, be related to physical and emotional problems, such as eating disorders, depression, suicidal ideation or even suicide itself 3,4 .

Several factors have been associated with bullying victimization, including drug use and/or cigarette 5,6; low motor skills; sexual orientation 7,8; presence of a chronic disease 9; disabilities 10; deafness or hearing loss 11; socioeconomic factors 12; income inequality 13, discrimination based on ethnicity 14, and educational background of the parents 15 . The self-perception of being fat or thin, or the overweight/obesity condition often stands out amongst the factors associated with violence and bullying 16,17 .

A meta-analysis study conducted by van Geel et al. 18 identified that overweight/obese adolescents are more likely to be victims of bullying. In Brazil, according to the data extracted from the Brazilian Household Budget Survey conducted between 2008 and 2009, the prevalence of overweight/obesity among 10-19-year-old adolescents was 20.5\% 19. However, no nationwide research was found when it comes to the association between bullying and nutritional status in this age group. A recent study, carried out in Southeastern Brazil, identified that $7.8 \%$ of the adolescents reported being bullied in the last 30 days, and most of them were black boys, children under 13 years, children of mothers with lower levels of education, and students of private schools 20.

This study explored discrimination by social, cultural, economic, and anthropometric variables and analyzed the victimization of individuals who are discriminated against those who are not. The aim of this research was to estimate the prevalence of bullying and to verify its association with nutritional status, demographic and economic factors, as well as individual attributes among schoolchildren aged 11 to 14 years.

This study seeks to fill the gap and increase scientific knowledge of the factors associated with bullying by adopting intervention strategies to reduce discrimination against obesity, thinness, poverty, ethnicity, and other individual attributes.

\section{Methods}

\section{Participants/subjects}

Data used in this research are part of a school-based, cross-sectional epidemiological study conducted between 2012/2013 in Florianópolis, Santa Catarina State, Brazil. The study was sponsored by the Brazilian National Research Council (CNPq) and was approved by the Ethics Research Committee of the Federal University of Santa Catarina (protocol number: 120341/2012). The parents/guardians of all the participants signed an informed consent form approved by the Ethics Research Committee. Details are described on the methodological procedures, which are available in previous studies 21,22 .

In summary, this study used the cluster sampling process in all the schools as primary sampling units. To perform the selection, the schools were divided into 10 strata according to the administrative regions of the city of Florianópolis (Center, Continent, North, East, and South) and to the school type (public or private). Considering the total number of schools available for this study $(\mathrm{n}=85)$, 30 of them were randomly selected (35\% of schools), and about 50 children were evaluated within each stratum.

The sample was comprised of adolescents - both boys and girls - between 11 and 14 years of age who demonstrated appropriate cognitive abilities to respond to the proposed questionnaire. Simulations were conducted in the minimum detectable odds ratio, considering a different prevalence for the outcome. Such simulations were performed with the free software Open Epi (https://www. openepi.com/), version 3.0, to explain the prevalence of bullying in this study population. Based on the sample of adolescents obtained for each associated factor - with bilateral 95\% confidence interval (95\%CI) - and designing both the exposed and unexposed overweight/obesity factor without the 
nutritional status, the power of the estimated test in the total sample was $80 \%$. The minimum detectable odds ratio (OR) was 3.43 in the case of $5 \%$ odds out of the outcome and 1.09 , if the bullying OR reached $90 \%$.

We excluded adolescents with physical limitations from the anthropometric evaluation, as well as pregnant girls.

\section{Bullying}

A self-administered questionnaire was answered by the adolescents in classrooms to identify victims of bullying and its different levels of intensity. This questionnaire was applied to students aged from 9 to 14 years following methodological procedures to guarantee psychometric properties in relation to their content validity. The procedures for constructing and validating the questionnaire include: (a) review of literature to identify the factors and indicators related to bullying $1,2,3,4,5,6,7,8,9,10,11,12,13$, 14,15,16,17,18,19,20; (b) elaboration of a theoretical framework on bullying; (c) construction of the items of the questionnaire - operational definitions, constitutive definitions, operationalization of items, and definition of response categories; (d) theoretical analysis of the items (semantic and judgemental analyses), (e) pilot test and; (f) construction of the measurement scale and verification of the psychometric quality of the instrument based on the Item Response Theory (IRT). Such methodology has been used in several studies $23,24,25,26$.

The questionnaire was composed of 23 questions or items used to construct the variable: 12 questions on the type of aggression (physical, verbal, moral/psychological, sexual, and cyber bullying); 5 questions on the type of damage (involving symptoms or reactions, such as feeling offended, sad, bored, hurt, humiliated, ashamed, anxious, and worried); and 6 questions on the reasons for discrimination (related to the characteristics or attributes of the victim, such as economic status, body aesthetics, skin color, disability or illness or other characteristic of the victim).

The adolescents pointed out in the questionnaire the frequency with which they experienced each situation in the school in the past year (not once, rarely, almost every day). The score attributed to each response allowed for the allocation of adolescents on the bullying scale that ranged between 80 and 140 points (equivalent to the categories without bullying and severe bullying, respectively). According to the objective of this study, the bullying variable was considered in a dichotomous way, being categorized as: "not a victim of bullying" (with a score lower than 120 on the scale) and "victim of bullying" (with a score between 120 and 140).

\section{Individual attributes}

The variable related to the characteristics that motivated acts of aggression towards the adolescents was named "individual attribute related to bullying". The variable "individual attributes" was included in this study, as it has been mentioned in the literature very frequently, for being related to life habits, family relations, socioeconomic conditions, weight status, appearance, ethnicity (race or skin color), diseases and/or physical limitations. It is noteworthy that schoolchildren victims of bullying are usually discriminated by their individual differences, whether they are physical, behavioral or emotional characteristics 5,6,7,8,9,10,11,12,13,14,15,16,17,18,20.

These variables were collected using a self-administered questionnaire, which was answered by the adolescents. Through the questionnaire, the adolescents pointed out the reason for being discriminated in the last year, if that was the case. Bullying-related variables (adjectives) included fat, thin, tall, short, good-looking, ugly, rich, poor, mentioned ethnicity (race or skin color) or disabilities and/ or others. In this article, such variables were analyzed according to their occurrence (yes or no), being considered as covariables, independent variables or exposure variables in the association analysis of the outcome.

\section{Body mass index}

A team of anthropometrists measured weight and height according to the international standard technique 27 . The classification of body mass index (BMI) followed the recommendations of the 
World Health Organization (WHO) 28 - overweight/obesity: > +1SD (equivalent to BMI $\geq 25 \mathrm{~kg} / \mathrm{m}^{2}$ at 19 years). In this study, adolescents were classified into two categories: overweight/obese and not overweight/obese.

\section{Socioeconomic and demographic variables}

The socioeconomic and demographic variables from the answers of the parents or guardians and of the adolescents who participated in this study were categorized as follows: age (11, 12, 13, 14 years), sex (male, female), educational background of the mother (illiterate/did not attend school, some/ elementary school, some/high school, some/college degree), household monthly income (in Brazilian Reais (BRL) and converted into United States Dollars (USD), categorized into quartiles, where quartile 1: income of up to USD 650.00; quartile 2: USD 651.00 to USD 930.00; quartile 3: USD 931.00 to USD 1,860.00; and quartile 4: USD 1,861.00 or more), and school administrative type (public or private).

\section{Statistical analyses}

Database was created with double data entry through the EpiData software version 3.2 (http://www. epidata.dk/); Stata software version 11.0 (https://www.stata.com) was used for statistical analyses.

Descriptive, univariate and multivariate analyses were performed to assess the association between independent variables in the outcome of interest. The chi-square test was conducted to explore statistical differences between categorical variables. Logistic regression was carried out to explore the association between variables in the dichotomous outcome. Backward stepwise selection was applied, since all the variables collected were considered conceptually relevant.

Given the size of the sample and variability, the analyses were stratified by sex (male and female), admitting the existence of heterogeneous characteristics between the elements involved to have an argument supported by evidences from the literature, which showed some peculiarities in the tests performed in this study 1,2,5,10,18. The possibility of taking such findings was also considered and attributed to each stratum, showing differences in the behaviour between boys and girls. Adjustment for household income was a strategy to minimize possible bias considering this variable as a possible confounding factor, since it is associated with exposure and outcome and is not part of the causal chain that links exposure to outcome.

The inclusion of independent variables in the regression model was performed by blocks. Confidence intervals provided significant explanation for the results, whose two-tailed p-values were lower than $5 \%$. Initially, demographic and socioeconomic variables were included. Then, anthropometric variables and individual attributes related to discrimination were also included. A significance level of 0.20 was used to limit the inclusion of variables into the model, as well as adjusted OR and their $95 \%$ CI

\section{Results}

This study included 975 participants aged between 11 and 14 years; 635 (65\%) of them were attending public schools and 340 (35\%), private schools. Among the adolescents who participated in the research, $54.3 \%$ were girls aged 11 years (31\%). The economic condition variable indicated that $27.2 \%$ of the adolescents have household monthly income below USD 650.00 and $24.5 \%$ of them have income greater than USD 1,861. Boys had higher prevalence of overweight/obesity (33.5\%), and, only for this variable, we observed a difference between sexes $(\mathrm{p}=0.005)$. The prevalence of bullying was $12.3 \%$ for boys and $14 \%$ for girls. Out of the total sample, $13.2 \%$ have been bullied (Table 1).

In the univariate analysis, the variables age, sex, school type, education of the mother and household income were not associated with bullying (victimization). An association between BMI and bullying was found among adolescents considered overweight/obese (OR = 1.44, 95\%CI: 1.03; 2.02) (Table 2). After performing the univariate analysis, the variables anthropometric (overweight/obesity) and individual attributes remained with p-value $<0.20$, and they were included in the hierarchical model of multivariate analysis. The variables that remained significant in the hierarchical model were the ones related to individual attributes. 
Table 1

Description of the sample of schoolchildren aged 11 to 14 years from the public and private education network according to demographic, socioeconomic, anthropometric, and bullying variables, stratified by sex. Florianópolis, Santa Catarina State, Brazil, 2012-2013.

\begin{tabular}{|c|c|c|c|c|}
\hline Variables & $\begin{array}{l}\text { Total } \\
\text { n (\%) }\end{array}$ & $\begin{array}{l}\text { Male } \\
\text { n (\%) }\end{array}$ & $\begin{array}{c}\text { Female } \\
\text { n (\%) }\end{array}$ & p-value \\
\hline \multicolumn{5}{|l|}{ Age (years) } \\
\hline 11 & $296(30.4)$ & $132(29.6)$ & $164(31.0)$ & $0.463 *$ \\
\hline 12 & 282 (28.9) & $125(28.0)$ & 157 (29.7) & \\
\hline 13 & $254(26.1)$ & $127(28.5)$ & $127(24.0)$ & \\
\hline 14 & $143(14.7)$ & $62(13.9)$ & $81(15.3)$ & \\
\hline \multicolumn{5}{|l|}{ School type } \\
\hline Public & 635 (65.0) & 287 (64.4) & $348(65.8)$ & 0.640 * \\
\hline Private & $340(35.0)$ & 159 (35.6) & $181(34.2)$ & \\
\hline \multicolumn{5}{|l|}{ Mother's education ** } \\
\hline Illiterate/Did not attend school & $20(2.2)$ & $9(2.2)$ & $11(2.2)$ & $0.875 * \star \star$ \\
\hline Some/Elementary school & $241(26.4)$ & $104(25.2)$ & $137(27.4)$ & \\
\hline Some/High school & $315(34.5)$ & $147(35.6)$ & $168(33.7)$ & \\
\hline Some/College degree & 336 (36.9) & $153(37.0)$ & $183(36.7)$ & \\
\hline \multicolumn{5}{|l|}{ Household income (quartile) ** } \\
\hline 1 & $225(27.2)$ & $98(25.5)$ & $127(28.7)$ & 0.695 * \\
\hline 2 & $184(22.2)$ & $91(23.6)$ & $93(21.0)$ & \\
\hline 3 & $216(26.1)$ & $101(26.2)$ & $115(26.0)$ & \\
\hline 4 & $203(24.5)$ & $95(24.7)$ & $108(24.3)$ & \\
\hline \multicolumn{5}{|l|}{ Overweight/Obesity ** } \\
\hline No & $683(71.0)$ & 292 (66.5) & 391 (74.8) & 0.005 * \\
\hline Yes & $279(29.0)$ & $147(33.5)$ & $132(25.2)$ & \\
\hline \multicolumn{5}{|l|}{ Bullying (victim) ** } \\
\hline No & $794(86.8)$ & $363(87.7)$ & $431(86.0)$ & $0.462 *$ \\
\hline Yes & $121(13.2)$ & $51(12.3)$ & $70(14.0)$ & \\
\hline
\end{tabular}

* Chi-square of heterogeneity (Pearson) test;

** Variables with missing data: household income (missing data = 147); overweight/obesity (missing data = 13); mother's education (missing data $=63$ ); bullying (missing data $=60$ );

*** Chi-square trend test.

In the adjusted logistic regression model for household income, the odds ratio of bullying was 18.60 higher in boys discriminated for being "fat" when compared with those who have not being bullied for this specific reason ( $\mathrm{OR}=18.60$, 95\%CI: 2.80; 123.45, $\mathrm{p}=0.002)$. In addition, "good-looking" or "ugly", "disabled", and "tall" boys were more likely to report discrimination ( $<0.05$ ) (Table 3).

As for the girls, we observed they had higher odds of being victims of bullying for being "fat" (OR = 5.80, 95\%CI: 1.24; 27.20, p = 0.026). “Tall”, "short”, "ugly”, or "poor" girls were more likely to report having been bullied $(\mathrm{p}<0.05)$ (Table 4$)$.

Adolescents of both sexes discriminated for being "fat", "ugly" or "tall" had higher odds of being considered victims of bullying at different levels. The adolescents who suffered discrimination due to "ethnicity" and "weight" showed no significant adjustment for both boys and girls. Discrimination for being "poor" and "other characteristics" remained associated with a higher prevalence of peer victimization only for girls (Tables 3 and 4). 


\section{Table 2}

Prevalence of bullying according to socioeconomic, demographic, anthropometric and individual attributes among schoolchildren aged 11 to 14 years from the public and private education network. Florianópolis, Santa Catarina State, Brazil, 2012-2013.

\begin{tabular}{|c|c|c|c|c|}
\hline Variables & $\mathbf{n}$ & $\%$ of bullying $(95 \% \mathrm{Cl})$ & OR $(95 \% \mathrm{Cl})$ & p-value \\
\hline \multicolumn{5}{|l|}{ Sex ** } \\
\hline Male & 414 & $12.32(9.14 ; 15.50)$ & 1.00 & 0.464 * \\
\hline Female & 501 & $13.97(10.93 ; 17.02)$ & $1.13(0.81 ; 1.59)$ & \\
\hline \multicolumn{5}{|l|}{ Age (years) ** } \\
\hline 11 & 285 & $15.09(10.90 ; 19.27)$ & 1.00 & 0.707 * \\
\hline 12 & 265 & $12.45(8.45 ; 16 ; 45)$ & $1.31(0.76 ; 2.38)$ & \\
\hline 13 & 234 & $12.82(8.50 ; 17.14)$ & $1.09(0.61 ; 1.93)$ & \\
\hline 14 & 131 & $15.45(5.92 ; 16.98)$ & $1.12(0.63 ; 2.00)$ & \\
\hline \multicolumn{5}{|l|}{ School type ** } \\
\hline Public & 635 & $14.02(11.31 ; 16.72)$ & 1.00 & 0.291 * \\
\hline Private & 280 & $11.43(7.68 ; 15.18)$ & $0.82(0.56 ; 1.19)$ & \\
\hline \multicolumn{5}{|l|}{ Mother's education ** } \\
\hline Illiterate/Did not attend school & 20 & $15.00(2.15 ; 32 ; 15)$ & 1.00 & $0.765 * * *$ \\
\hline Some/Elementary school & 237 & $13.08(8.75 ; 17.40$ & $0.87(0.29 ; 2.60)$ & \\
\hline Some/High school & 312 & $14.10(10.21 ; 17.99)$ & $0.94(0.32 ; 2.77)$ & \\
\hline Some/College degree & 284 & $11.37(7.57 ; 14.97)$ & $0.75(0.25 ; 2.24)$ & \\
\hline \multicolumn{5}{|l|}{ Household income (quartile) ** } \\
\hline 1 & 225 & $13.78(9.24 ; 18.32)$ & 1.00 & 0.089 * \\
\hline 2 & 184 & $17.39(11.86 ; 22.92)$ & $1.26(0.80 ; 1.99)$ & \\
\hline 3 & 207 & $10.14(6.00 ; 14.29)$ & $0.74(0.44 ; 1.24)$ & \\
\hline 4 & 168 & $9.52(5.04 ; 14.01)$ & $0.70(0.40 ; 1.22)$ & \\
\hline \multicolumn{5}{|l|}{ Overweight/Obesity ** } \\
\hline No & 626 & $11.82(9.29 ; 14.36)$ & 1.00 & $0.034 * \star *$ \\
\hline Yes & 276 & $17.03(12.57 ; 21.49)$ & $1.44(1.03 ; 2.02)$ & \\
\hline \multicolumn{5}{|l|}{ Fat ** } \\
\hline No & 772 & $9.07(7.04 ; 11.10)$ & 1.00 & $<0.001$ * \\
\hline Yes & 111 & $41.44(32.13 ; 50.75)$ & $4.57(3.38 ; 6.26)$ & \\
\hline \multicolumn{5}{|l|}{ Thin ** } \\
\hline No & 762 & $10.50(8.32 ; 12.69)$ & 1.00 & $<0.001$ * \\
\hline Yes & 117 & $29.91(21.49 ; 38.33)$ & $2.85(2.02 ; 4.03)$ & \\
\hline \multicolumn{5}{|l|}{ Tall ** } \\
\hline No & 805 & $10.43(8.32 ; 12.55)$ & 1.00 & $<0.001$ * \\
\hline Yes & 74 & $40.54(29.09 ; 51.99)$ & $3.89(2.76 ; 5.47)$ & \\
\hline \multicolumn{5}{|l|}{ Short ** } \\
\hline No & 772 & $10.75(8.56 ; 12.94)$ & 1.00 & $<0.001$ * \\
\hline Yes & 102 & $27.45(18.64 ; 36.26)$ & $2.55(1.75 ; 3.72)$ & \\
\hline \multicolumn{5}{|l|}{ Good-looking ** } \\
\hline No & 787 & $9.28(7.24 ; 11.30)$ & 1.00 & $<0.001$ * \\
\hline Yes & 88 & $43.18(32.63 ; 53.74)$ & $4.65(3.37 ; 6.44)$ & \\
\hline \multicolumn{5}{|l|}{ Ugly ** } \\
\hline No & 777 & $7.72(5.84 ; 9.60)$ & 1.00 & $<0.001$ * \\
\hline Yes & 102 & $53.92(44.08 ; 63.76)$ & $6.98(5.16 ; 9.44)$ & \\
\hline \multicolumn{5}{|l|}{ Rich ** } \\
\hline No & 852 & 12.09 (9.90; 14.28) & 1.00 & $<0.001$ * \\
\hline Yes & 23 & 34.78 (13.72; 55.84) & $2.88(1.60 ; 5.18)$ & \\
\hline
\end{tabular}

(continues) 
Table 2 (continued)

\begin{tabular}{|c|c|c|c|c|}
\hline Variables & $\mathbf{n}$ & $\%$ of bullying $(95 \% \mathrm{Cl})$ & OR $(95 \% \mathrm{Cl})$ & p-value \\
\hline \multicolumn{5}{|l|}{ Poor ** } \\
\hline No & 842 & $10.33(8.27 ; 12.39)$ & 1.00 & $<0.001$ * \\
\hline Yes & 37 & $72.97(57.96 ; 87.98)$ & $7.06(5.34 ; 9.34)$ & \\
\hline \multicolumn{5}{|c|}{ Ethnicity (race or skin color) ** } \\
\hline No & 821 & $10.35(8.26 ; 12.44)$ & 1.00 & $<0.001$ * \\
\hline Yes & 54 & $48.15(34.38 ; 61.91)$ & $4.65(3.30 ; 6.55)$ & \\
\hline \multicolumn{5}{|c|}{ Disability ** } \\
\hline No & 849 & $11.43(9.28 ; 13.57)$ & 1.00 & $<0.001$ * \\
\hline Yes & 24 & $58.33(37.07 ; 79.60)$ & $5.11(3.47 ; 7.52)$ & \\
\hline \multicolumn{5}{|l|}{ Other ** } \\
\hline No & 640 & $9.22(6.97 ; 11.47)$ & 1.00 & $<0.001$ * \\
\hline Yes & 43 & $46.51(30.98 ; 62.04)$ & $5.05(3.37 ; 7.54)$ & \\
\hline
\end{tabular}

95\%Cl: 95\% confidence interval; OR: odds ratio.

* Chi-square of heterogeneity (Pearson) test;

** Variable with missing data: mother's education (missing data = 62); household income (missing data = 131); overweight/obesity (missing data = 13); fat (missing data = 32); thin, ugly and poor (missing data =36); tall (missing data = 26); short (missing data = 41); good-looking, rich and ethnicity ( $r a c e$ or skin color) (missing data $=40$ ); disability (missing data $=42$ ); other (missing data $=232$ );

$\star \star \star *$ Chi-square trend test.

\section{Table 3}

Crude and adjusted analyses of odds ratio (OR) for victims of bullying according to the anthropometric and individual attributes, for male schoolchildren aged 11 to 14 years from the public and private education network. Florianópolis, Santa Catarina State, Brazil, 2012-2013.

\begin{tabular}{|c|c|c|c|c|}
\hline Variables & OR crude $(95 \% \mathrm{Cl})$ & $p$-value & OR adjusted $(95 \% \mathrm{Cl})$ * & p-value \\
\hline Overweight/Obesity & & 0.016 & & 0.089 \\
\hline No & 1.00 & & 1.00 & \\
\hline Yes & $2.07(1.15 ; 3.74)$ & & $5.88(0.76 ; 45.38)$ & \\
\hline Fat & & $<0.001$ & & 0.002 \\
\hline No & 1.00 & & 1.00 & \\
\hline Yes & $8.02(4.10 ; 15.71)$ & & $18.60(2.80 ; 123.45)$ & \\
\hline Thin & & $<0.001$ & & 0.110 \\
\hline No & 1.00 & & 1.00 & \\
\hline Yes & $3.74(1.83 ; 7.66)$ & & $6.07(0.67 ; 55.28)$ & \\
\hline Tall & & $<0.001$ & & 0.039 \\
\hline No & 1.00 & & 1.00 & \\
\hline Yes & $8.70(3.90 ; 19.39)$ & & $9.29(1.11 ; 75.52)$ & \\
\hline Short & & 0.088 & & 0.134 \\
\hline No & 1.00 & & 1.00 & \\
\hline Yes & $2.19(0.89 ; 5.37)$ & & $5.17(0.60 ; 44.29)$ & \\
\hline Good-looking & & $<0.001$ & & 0.009 \\
\hline No & 1.00 & & 1.00 & \\
\hline Yes & $6.30(2.95 ; 13.47)$ & & $11.50(1.84 ; 71.74)$ & \\
\hline Ugly & & $<0.001$ & & 0.017 \\
\hline No & 1.00 & & 1.00 & \\
\hline Yes & $11.74(5.74 ; 24.19)$ & & $8.19(1.46 ; 45.80)$ & \\
\hline
\end{tabular}

(continues) 
Table 3 (continues)

\begin{tabular}{|c|c|c|c|c|}
\hline Variables & OR crude $(95 \% \mathrm{Cl})$ & p-value & OR adjusted $(95 \% \mathrm{Cl})$ * & p-value \\
\hline Rich & & 0.067 & & 0.485 \\
\hline No & 1.00 & & 1.00 & \\
\hline Yes & $3.39(0.92 ; 12.51)$ & & $2.69(0.69 ; 10.43)$ & \\
\hline Poor & & 0.014 & & 0.090 \\
\hline No & 1.00 & & 1.00 & \\
\hline Yes & $6.64(1.48 ; 29.82)$ & & $5.54(1.20 ; 25.63)$ & \\
\hline Ethnicity (race or skin color) & & $<0.001$ & & 0.077 \\
\hline No & 1.00 & & 1.00 & \\
\hline Yes & $12.25(5.26 ; 28.53)$ & & $9.50(0.79 ; 114.70)$ & \\
\hline Disability & & $<0.001$ & & 0.007 \\
\hline No & 1.00 & & 1.00 & \\
\hline Yes & $16.80(5.34 ; 52.84)$ & & $84.99(3.47 ; 284.16)$ & \\
\hline Other & & $<0.001$ & & 0.067 \\
\hline No & 1.00 & & 1.00 & \\
\hline Yes & $8.39(3.37 ; 20.86)$ & & $6.77(0.87 ; 52.56)$ & \\
\hline
\end{tabular}

95\%Cl: 95\% confidence interval.

* OR adjusted for household income.

\section{Discussion}

The main results of this study show the prevalence of victims of bullying and overweight/obesity was $13.2 \%$ and $29 \%$, respectively. In the crude analysis model, the association between bullying and overweight/obesity and the variables called individual attributes (fat, thin, tall, short, good-looking, ugly, rich, poor, regarding ethnicity or disabilities and/or others) indicated that the adolescents discriminated for having such attributes had a greater chance of being victims of bullying. In the analysis model adjusted by household income and stratified by sex, we verified that the individual attributes associated with bullying were different amongst boys (fat, good-looking, ugly and with a disability) and girls (fat, tall, short, ugly, rich, poor, and others). This study found no association between bullying and the investigated variables such as age, sex, school type, education of the mother, household income, and overweight/obesity.

The prevalence of bullying in studies conducted in the United States, and in European, Asian and Latin American countries, including Brazil, varied from $7.4 \% 29$ to $72 \% 30$. In relation to this study, we found a higher prevalence of bullying in nine other studies $5,30,31,32,33,34,35,36,37$, a similar prevalence in three other studies 38,39,40, and lower prevalence in two other studies 29,41 .

These variations may be explained by the different methodological procedures used in the studies and the criteria adopted for bullying classification, in addition to the explanatory model of the phenomenon, given that it is a multifaceted construction comprised of different domains. Distinct geographic and temporal contexts, differences in age range and size of the samples investigated can also be considered explanatory factors for the wide variation among studies. Therefore, we highlight the difficulty in discussing more broadly and accurately our results in relation to the literature, due to the different instruments and methodological procedures used to measure both the outcome variable (bullying) and the exposure variable (overweight/obesity).

Even though sex was not associated with prevalence of bullying, some specific behaviors were observed for boys and girls, such as the association of frequent discrimination for being "short", "poor" and/or "ugly", which only remained significant in girls after adjustment. These results presented a different behavior from those observed in other studies. One cross-sectional study conducted in Italy 42 with children and adolescents aged 6 to 14 years identified that obese individuals were more involved in bullying episodes (information collected through a questionnaire answered by the schoolchildren themselves). In addition, severely obese participants experienced verbal and physical victimization 


\section{Table 4}

Crude and adjusted analyses of odds ratio (OR) for victims of bullying according to the anthropometric and individual attributes, for female schoolchildren aged 11 to 14 years from the public and private education network. Florianópolis, Santa Catarina State, Brazil, 2012-2013.

\begin{tabular}{|c|c|c|c|c|}
\hline Variables & OR crude $(95 \% \mathrm{CI})$ & $p$-value & OR adjusted $(95 \% \mathrm{Cl})$ * & p-value \\
\hline Overweight/Obesity & & 0.470 & & 0.973 \\
\hline No & 1.00 & & 1.00 & \\
\hline Yes & $1.23(0.70 ; 2.14)$ & & $1.02(0.25 ; 4.16)$ & \\
\hline Fat & & $<0.001$ & & 0.026 \\
\hline No & 1.00 & & 1.00 & \\
\hline Yes & $6.63(3.59 ; 12.26)$ & & $5.80(1.24 ; 27.20)$ & \\
\hline Thin & & $<0.001$ & & 0.074 \\
\hline No & 1.00 & & 1.00 & \\
\hline Yes & $3.55(1.95 ; 6.45)$ & & $3.33(0.89 ; 12.42)$ & \\
\hline Tall & & $<0.001$ & & 0.002 \\
\hline No & 1.00 & & 1.00 & \\
\hline Yes & $4.40(2.23 ; 8.69)$ & & $11.90(2.50 ; 55.49)$ & \\
\hline Short & & $<0.001$ & & $<0.001$ \\
\hline No & 1.00 & & 1.00 & \\
\hline Yes & $3.70(2.03 ; 6.74)$ & & $9.21(2.39 ; 35.71)$ & \\
\hline Good-looking & & $<0.001$ & & 0.092 \\
\hline No & 1.00 & & 1.00 & \\
\hline Yes & $8.32(4.41 ; 15.70)$ & & $3.43(0.82 ; 14.39)$ & \\
\hline Ugly & & $<0.001$ & & $<0.001$ \\
\hline No & 1.00 & & 1.00 & \\
\hline Yes & $15.84(8.49 ; 29.56)$ & & $41.30(8.81 ; 193.54)$ & \\
\hline Rich & & 0.039 & & 0.039 \\
\hline No & 1.00 & & 1.00 & \\
\hline Yes & $8.89(1.12 ; 70.69)$ & & $6.30(1.12 ; 70.69)$ & \\
\hline Poor & & 0.003 & & $<0.001$ \\
\hline No & 1.00 & & 1.00 & \\
\hline Yes & $21.73(2.90 ; 162.90)$ & & $21.55(2.84 ; 163.23)$ & \\
\hline Ethnicity (race or skin color) & & $<0.001$ & & 0.073 \\
\hline No & 1.00 & & 1.00 & \\
\hline Yes & $5.80(2.58 ; 13.08)$ & & $5.06(0.86 ; 29.76)$ & \\
\hline Disability & & 0.003 & & 0.149 \\
\hline No & 1.00 & & 1.00 & \\
\hline Yes & $6.82(1.92 ; 24.24)$ & & $7.18(0.49 ; 104.39)$ & \\
\hline Other & & $<0.001$ & & 0.004 \\
\hline No & 1.00 & & 1.00 & \\
\hline Yes & $10.27(3.81 ; 27.65)$ & & $22.26(2.74 ; 181.06)$ & \\
\hline
\end{tabular}

95\% Cl: 95\% confidence interval.

* OR adjusted for household income.

and exclusion from group activities 42 . For the diagnosis of obesity, this Italian study used the cut-off points of BMI recommended by the Centers for Disease Control and Prevention (CDC). The BMI standard deviation score (BMI-SDS) was employed to define normal-weight (BMI-SDS between -1 and +1); overweight (BMI-SDS between 1.01 and 1.63), moderate obesity (SDS-BMI between 1.64 and 2.5); and severe obesity (BMI-SDS > 2.5) 42 . 
A cohort study conducted in England 43 found that bullying episodes have become more frequent over the years when it comes to the English population. This study identified that, at the age of eighteen, individuals intimidated by others are more likely to be overweight than those who are not bullied. Such association was even stronger in chronically intimidated individuals. In addition to the longitudinal design (follow-up of children from birth to 18 years of age), this English study obtained the information on victims of bullying from questionnaires applied with mothers and with the schoolchildren themselves. For the diagnosis of overweight/obesity, they used the cut-off points of the BMI recommended by the CDC (BMI equal to or above the 85 th percentile were classified as overweight), as well as other measures, such as waist-hip ratio and a visual assessment of weight performed subjectively by the examiners. Such evaluations were performed at different times, in particular, at the ages of 7, 10 and 12 years 43, age groups that resemble this study.

Investigations have shown that prevalence of bullying has a specific behavior according to the sex and depends on other physical or mental characteristics. Also, the victims are usually individuals with low self-esteem, who are shy or emotionally fragile, especially girls who deviate from the aesthetic standards imposed by society 1,2,5,10,18,31,35,37,41,42,44.

In this study, both sex and physical appearance (measured by individual variables) were a determinant of bullying in the adolescents investigated, which was also observed in other studies 12,45,46,47. Furthermore, by revealing the association between being discriminated and being bullied, for both sexes, the findings show that this phenomenon is a risk factor, particularly in societies that value an ideal body based on weight, which may lead to discrimination in various contexts 48,49 .

Our results showed that adolescents of both sexes discriminated for being fat, thin, tall, short, good-looking, poor or other characteristics are more likely to being bullied. These findings confirm that, within the peer victimization process, individuals who are judged by their individual characteristics show a greater predominance of negative actions in relation to their colleagues, thus leading to conflicts related to culturally valued standards in which differences are not well-accepted 1,2,3,4,5,6,7,8,9,10,11,12,13,14,15.

Regarding the factors associated with bullying victimization in adolescents, a few studies carried out in Brazil in the last ten years must be mentioned. Several studies using data from the Brazilian National Survey of School Health (PeNSE) have made it possible to monitor the pattern of bullying victimization and associated factors in adolescents in the 9th year of primary education in the Brazilian capitals. In these studies, the prevalence of bullying among the adolescents investigated was $5.4 \%, 7.2 \%$, and $7.4 \%$ in the years 2009,2012 , and 2015 , respectively, showing a pattern of victimization related to percentage increase. Regarding the factors investigated, such studies have pointed out that black boys younger than 13 years, as well as indigenous adolescents from public school, children of mothers with a lower level of schooling, lonely adolescents who suffer from insomnia, physical aggression from their relatives, who missed classes without warning their parents, as well as smokers 50,51,52.

An interesting analysis using PeNSE 2012 data found that 51.2\% among the causes of bullying could not be specified. The second highest frequency of victimization was related to physical appearance (18.6\%), followed by good looks (16.2\%), race/color (6.8\%), sexual orientation (2.9\%), religion (2.5\%), and region of origin (1.7\%) 53. Two other Brazilian studies with localized populations showed a prevalence of $17.6 \%$ (in students from 1st to 8 th grades) 37 and $29.5 \%$ (in students from 6 th to 9 th grade) 54 , such as those found in PeNSE. They have also pointed out a higher prevalence in boys.

This study found no association between bullying and overweight/obesity, thus contrasting with the results verified by other studies. A study conducted in China 55 with children and adolescents between 7 and 18 years showed that the risk of bullying increased among obese students; however, it was only considered statistically significant among women. Another study, conducted in Norway 56, with children and adolescents between 10 and 20 years, also found an association between interpersonal violence and higher BMI. A meta-analysis on the relation between weight status and bullying, published in 2014, included 14 articles $(\mathrm{N}=55,231)$ and has verified that both overweight and obese youths were more likely to being bullied. The results were not moderated by sex and weight. Therefore, obese boys and girls were equally likely to be discriminated. The study concluded that both overweight and obesity are risk factors of bullying victimization 18 . 
For this reason, to pay attention to the individual and to the contextual factors, such as household income and discriminatory behaviors based on individual attributes, is fundamental to explain the impacts of this phenomenon.

This study has several strengths and limitations that need to be pointed out. Regarding its strengths, it is noteworthy that (1) this is a pioneering study showing the prevalence of victims of bullying through a questionnaire based on IRT 23,24,25,26; (2) the methods adopted for sample calculation and selection used a sample with representative data on the schoolchildren population from Florianópolis; (3) the study used methodological rigor and considered a standardization of anthropometric measurements and other variables; and (4) it also used double data entry to avoid biased compilation. There are some methodological advantages indicating rigor and reliability on the results in the way they are exposed.

On the other hand, this study also presents some weaknesses. First, the cross-sectional data collection did not make it possible to infer the temporality of relationships between bullying and the exposure variables investigated. Second, the missing data for some of the variables, such as household income and educational level of the mother, among others, can be pointed out as one of the limitations of this study, which may have implications in the evidences produced and, consequently, hinder their internal validity. Third, we emphasize that the methodological procedures used to categorize the overweight/obesity variable (BMI > +1SD) and other characteristics of the age group (11 to 14 years), such as those related to sexual maturation, may have influenced the findings of this study, showing no association between overweight/obesity and bullying. Therefore, such results must be cautiously understood and other methodological procedures and variables related to the diagnosis of overweight/obesity of schoolchildren aged 7 to 14 years must be added into the analysis models in future research.

\section{Conclusion}

In this study, the prevalence of bullying and overweight/obesity in schoolchildren aged 11 to 14 years was $13.2 \%$ and $29 \%$, respectively. No association was found between the outcome and the exposure variables for the investigated sample - age, sex, school type, mother's education, household income, and overweight/obesity. On the other hand, in the analysis model adjusted by household income and stratified by sex, we verified that fat, good-looking, ugly, and boys with disabilities, as well as fat, tall, short, ugly, rich, and poor girls had greater chance of becoming victims of bullying.

These results reinforce the need to adopt intervention programs in schools to reduce the prevalence of overweight/obesity, as well as the discrimination behaviors related to obesity and other individual attributes. Finally, we emphasize that attributes are individual characteristics, but bullying and obesity are social problems. Even though this study brings some evidence, further research is needed to provide a better understanding of the magnitude of such phenomena.

\section{Contributors}

S. L. Alexius worked in all stages of the research, such as project design, data collection, data analysis and interpretation, and writing of the manuscript. M. C. Mocellin, E. N. Corrêa, J. Neves, and F. A. G Vasconcelos participated in the writing of the manuscript and revision of the final text. A. C. T. Corso guided all steps of the research, such as project design, data collection, data analysis and interpretation, manuscript idealization and revision of the final text. All authors participated in the review, drafting, and final approval of the manuscript.

\section{Acknowledgments}

We express a big thanks to all participants in our study: parents, schools and the adolescents. 


\section{References}

1. Barlett C, Coyne SM. A meta-analysis of sex differences in cyber-bullying behavior: the moderating role of age. Aggress Behav 2014; 40:474-88.

2. Olweus D. Bullying at school: what we know and what we can do. Oxford: Blackwell; 1993.

3. Mueller AS, James W, Abrutyn S, Levin ML. Suicide ideation and bullying among US adolescents: examining the intersections of sexual orientation, gender, and race/ethnicity. Am J Public Health 2015; 105:980-5.

4. Moore SE, Norman RE, Suetani S, Thomas HJ, Sly PD, Scott JG. Consequences of bullying victimization in childhood and adolescence: a systematic review and meta-analysis. World J Psychiatr 2017; 7:60-76.

5. Andrade SSCA, Yokota RT, Sá NNB, Silva MMA, Araújo WN, Mascarenhas MDM, et al. Relação entre violência física, consumo de álcool e outras drogas e bullying entre adolescentes escolares brasileiros. Cad Saúde Pública 2012; 28:1725-36.

6. Radliff KM, Wheaton JE, Robinson K, Morris J. Illuminating the relationship between bullying and substance use among middle and high school youth. Addict Behav 2012; 37:569-72.

7. Garnett BR, Masyn KE, Austin SB, Miller M, Williams DR, Viswanath K. The intersectionality of discrimination attributes and bullying among youth: an applied latent class analysis. J Youth Adolesc 2014; 43:1225-39.

8. Eisenberg ME, Gower AL, McMorris BJ. Emotional health of lesbian, gay, bisexual and questioning bullies: does it differ from straight bullies? J Youth Adolesc 2016; 45:105-16.

9. Van Cleave J, Davis MM. Bullying and peer victimization among children with special health care needs. Pediatrics 2006; 118:e1212-9.

10. Rose CA, Espelage DL, Monda-Amaya LE, Shogren KA, Aragon SR. Bullying and middle school students with and without specific learning disabilities: an examination of socialecological predictors. J Learn Disabil 2015; 48:239-54.

11. Kouwenberg M, Rieffe C, Theunissen SC, de Rooij M. Peer victimization experienced by children and adolescents who are deaf or hard of hearing. PLoS One 2012; 7:e52174.

12. Bejerot S, Plenty S, Humble A, Humble MB. Poor motor skills: a risk marker for bully victimization. Aggress Behav 2013; 39:453-61.

13. Azeredo CM, Rinaldi AEMR, Moraes CL, Levy RB, Menezes PR. School bullying: a systematic review of contextual-level risk factors in observational studies. Aggress Violent Behav 2015; 22:65-76.

14. Hepburn L, Azrael D, Molnar B, Miller M. Bullying and suicidal behaviors among urban high school youth. J Adolesc Health 2012; 51:93-5.

15. Lumeng JC, Forrest P, Appugliese DP, Kaciroti $\mathrm{N}$, Corwyn RF, Bradley RH. Weight status as a predictor of being bullied in third through sixth grades. Pediatrics 2010; 125:e1301-7.
16. Midei AJ, Matthews KA. Interpersonal violence in childhood as a risk factor for obesity: a systematic review of the literature and proposed pathways. Obes Rev 2011; 12:e159-72.

17. Gee KA. School-based body mass index screening and parental notification in late adolescence: evidence from Arkansas's Act 1220 J Adolesc Health 2015; 57:270-6.

18. van Geel M, Vedder P, Tanilon J. Are overweight and obese youths more often bullied by their peers? A meta-analysis on the relation between weight status and bullying. Int J Obes 2014; 38:1263-7.

19. Instituto Brasileiro de Geografia e Estatística. Pesquisa de Orçamentos Familiares 20082009: antropometria e estado nutricional de crianças, adolescentes e adultos do Brasil. Rio de Janeiro: Instituto Brasileiro de Geografia e Estatística; 2010.

20. Mello FCM, Malta DC, Prado RR, Farias MS, Alencastro LCS, Silva MAI. Bullying e fatores associados em adolescentes da Região Sudeste segundo a Pesquisa Nacional de Saúde do Escolar. Rev Bras Epidemiol 2016; 19:866-77.

21. D’Avila GL, Muller RL, Gonsalez PS, Vasconcelos FAG. Associação entre estado nutricional da mãe, fatores sociodemográficos, frequência, local e companhia durante as refeições e prevalência de sobrepeso/obesidade em adolescentes de Florianópolis, SC: um estudo transversal. Rev Bras Saúde Matern Infant 2015; 15:289-99.

22. Motter AF, Vasconcelos FAG, Corrêa EN, Andrade DF. Pontos de venda de alimentos e associação com sobrepeso/obesidade em escolares de Florianópolis, Santa Catarina, Brasil. Cad Saúde Pública 2015; 31:620-32.

23. Cúri M, Singer JM, Andrade DF. A model for psychiatric questionnaires with embarrassing items. Stat Methods Med Res 2011; 20:451-70.

24. Bortolotti S, Vincenzi L, Tezza R, Andrade, DF Bornia, AC, Sousa Júnior AF. Relevance and advantages of using the item response theory. Qual Quant 2013; 47:2341-60.

25. Rodrigues MTP, Moreira TMM, Andrade, DF Elaboração e validação de instrumento avaliador da adesão ao tratamento da hipertensão. Rev Saúde Pública 2014; 48:232-40.

26. Samejima F. Estimation of latent ability using a response pattern of graded scores. Richmond: Psychometric Society; 1969. (Psychometric Monograph, 17).

27. Lohman TG. Anthropometric assessment of fat-free body mass. In: Himes JH, editor. Anthropometric assessment of nutritional status. Champaign: Human Kinetics Publishers; 1991. p. 173-83.

28. de Onis M, Onyango AW, Borghi E, Siyam A, Nishida C, Siekmann J. Development of a WHO growth reference for school-aged children and adolescents. Bull World Health Organ 2007; 85:660-7. 
29. Farhat T, Iannotti RJ, Simons-Morton BG. Overweight, obesity, youth, and health-risk behaviors. Am J Prev Med 2010; 38:258-67.

30. Juvonen J, Gross EF. Extending the school grounds?: Bullying experiences in cyberspace. J Sch Health 2008; 78:496-505.

31. Brito CC, Oliveira MT. Bullying and self-esteem in adolescents from public schools. $\mathrm{J} \mathrm{Pe}$ diatr (Rio J.) 2013; 89:601-7.

32. Puhl RM, Peterson JL, Luedicke J. Weightbased victimization: bullying experiences of weight loss treatment-seeking youth. Pediatrics 2013; 131:e1-9.

33. Romo ML, Kelvin EA. Impact of bullying victimization on suicide and negative health behaviors among adolescents in Latin America. Rev Panam Salud Pública 2016; 40:347-55.

34. Lourenço LM, Pereira B, Paiva DP, Gebara C. A gestão educacional e o bullying: um estudo em escolas portuguesas. Interacções 2009; 5:208-28.

35. Pengpid S, Peltzer K. Bullying and its associated factors among school-aged adolescents in Thailand. ScientificWorldJournal 2013; 2013:e1-6.

36. Francisco MV, Liborio RMC. Um estudo sobre bullying entre escolares do ensino fundamental. Psicol Reflex Crít 2009; 22:200-7.

37. Moura DR, Cruz AC, Quevedo LA. Prevalence and characteristics of school age bullying victims. J Pediatr (Rio J.) 2011; 87:19-23.

38. Kowalski RM, Limber SP. Psychological, physical, and academic correlates of cyberbullying and traditional bullying. J Adolesc Health 2013; 53(1 Suppl):S13-20.

39. Pardo IMCG, Souza SS, Lima NCB, Nascimento RRD, Santucci VCR, Martinez JE. A escola é um lugar seguro? Prevalência de bullying em uma amostra de estudantes de ensino médio público de Sorocaba. Rev Fac Ciênc Med Sorocaba 2012; 14:100-4.

40. Jansen PW, Verlinden M, Dommisse-van Berkel A, Mieloo C, van der Ende J, Veenstra R, et al. Prevalence of bullying and victimization among children in early elementary school: do family and school neighbourhood socioeconomic status matter? BMC Public Health 2012; 12:494.

41. Rech RR, Halpern R, Tedesco A, Santos DF. Prevalence and characteristics of victims and perpetrators of bullying. J Pediatr (Rio J.) 2013; 89:164-70

42. Bacchini D, Licenziati MR, Garrasi A, Corciulo N, Driul D, Tanas R, et al. Bullying and victimization in overweight and obese outpatient children and adolescents: an Italian Multicentric Study. PLoS One 2015; 10:e0142715.

43. Baldwin JR, Arseneault L, Odgers C, Belsky DW, Matthews T, Ambler A, et al. Childhood bullying victimization and overweight in young adulthood: a cohort study. Psychosom Med 2016; 78:1094-103.

44. Pigozi PL, Machado AL. Bullying na adolescência: visão panorâmica no Brasil. Ciênc Saúde Coletiva 2015; 20:3509-22.
45. Puhl RM, Luedicke J, Heuer C. Weight-based victimization toward overweight adolescents: observations and reactions of peers. J Sch Health 2011; 81:696-703.

46. Reulbach U, Ladewig EL, Nixon E, O’Moore M, Williams J, O'Dowd T. Weight, body image and bullying in 9-year-old children. J Paediatr Child Health 2013; 49:E288-93.

47. Almenara CA, Jezek S. The source and impact of appearance teasing: an examination by sex and weight status among early adolescents from the Czech Republic. J Sch Health 2015; 85:163-70.

48. Klein J, Cornell D, Konold T. Relationships between bullying, school climate, and student risk behaviors. Sch Psychol Q 2012; 27:154-69.

49. Puhl RM, Luedicke J. Weight-based victimization among adolescents in the school setting: emotional reactions and coping behaviors. J Youth Adolesc 2012; 41:27-40.

50. Malta DC, Porto DL, Crespo CD, Silva MMA, Andrade SSC, Mello FCM, et al. Bullying and associated factors among Brazilian adolescents: analysis of the National Adolescent School-based Health Survey (PeNSE 2012). Rev Bras Epidemiol 2014; 17 Suppl 1:131-45.

51. Mello FCM, Malta DC, Prado RR, Farias MS, Alencastro LCS, Silva MAI. Bullying e fatores associados em adolescentes da Região Sudeste segundo a Pesquisa Nacional de Saúde do Escolar. Rev Bras Epidemiol 2016; 19:866-77.

52. Malta DC, Mello FCM, Prado RR, Sá ACMGN, Marinho de Souza MF, Pinto I, et al. Prevalência de bullying e fatores associados em escolares brasileiros, 2015. Ciênc Saúde Coletiva 2017; ahead of print. http://www.cienciae saudecoletiva.com.br/artigos/prevalencia-debullying-e-fatores-associados-em-escolaresbrasileiros-2015/16356.

53. Oliveira WA, Silva MAI, Mello FCM, Porto DL, Yoshinaga ACM, Malta DC. The causes of bullying: results from the National Survey of School Health (PeNSE). Rev Latinoam Enferm 2015; 23:275-82.

54. Marcolino EC, Cavalcanti AL, Padilha WWN, Miranda FAN, Clementino FS. Bullying: prevalência e fatores associados à vitimização e à agressão no cotidiano escolar. Texto Contexto Enferm 2018; 27:e5500016.

55. Liu X, Chen G, Yan J, Luo J. Weight status and bullying behaviors among Chinese schoolaged children. Child Abuse Neglect 2016; 52:11-9.

56. Stensland SØ, Thoresen S, Wentzel-Larsen T, Dyb G. Interpersonal violence and overweight in adolescents: The HUNT Study. Scand J Public Health 2015; 43:18-26. 


\section{Resumo}

O estudo teve como objetivos estimar a prevalência de bullying e verificar a associação entre estado nutricional, fatores demográficos e socioeconômicos e atributos individuais em escolares entre 11 e 14 anos de idade. O estudo transversal usou uma amostra probabilística de 975 adolescentes matriculados em escolas públicas e privadas em Florianópolis, Santa Catarina, Brasil. O bullying foi investigado com um questionário auto-administrado, aplicando a Teoria da Resposta ao Item, e dicotomizado de acordo com a presença ou ausência de vitimização. $O$ índice de massa corporal (IMC) foi classificado de acordo com os critérios da Organização Mundial da Saúde. Dados como idade, tipo e localização da escola, renda familiar e escolaridade dos pais foram coletados com um questionário entregue aos pais ou responsáveis. A regressão logística foi usada para as análises brutas e ajustadas. As taxas de prevalência de vitimização pelo bullying e de sobrepeso/obesidade foram 13,2\% e 29\%, respectivamente. Não houve associação entre bullying e idade, gênero, tipo de escola, escolaridade materna, renda familiar ou sobrepeso/obesidade. A análise não-ajustada indicou que os adolescentes com sobrepeso/obesidade e aqueles com determinados atributos individuais (gordo, magro, alto, baixo, bonito, feio, pertencente a outro grupo étnico, rico, pobre, portador de deficiência e/ou outros) tinham maior probabilidade de sofrerem bullying. $\mathrm{Na}$ análise ajustada para renda familiar e estratificada por gênero, os meninos eram discriminados por serem gordos, bonitos, feios, ou por serem portadores de deficiência, enquanto as meninas eram discriminadas por serem gordas, altas, baixas, feias, ricas ou pobres, entre outros atributos individuais.

Comportamento do Adolescente; Bullying; Discriminação; Obesidade; Sobrepeso

\section{Resumen}

El objetivo de este estudio fue estimar la prevalencia de bullying y verificar la asociación entre estatus nutricional, factores demográficos y socioeconómicos, así como atributos individuales, entre escolares con edades comprendidas entre los 11 a los 14 años. Este estudio transversal con una muestra probabilística de 975 adolescentes inscritos en escuelas públicas y privadas en Florianópolis, Estado de Santa Catarina, Brasil. El bullying se investigó mediante un cuestionario autoadministrado, a través de la aplicación de la teoría respuesta al item y con dicotomización, según la existencia de victimización o no. El índice de masa corporal (IMC) se clasificó según criterios de la Organización Mundial de la Salud. Se recogieron datos como: edad, tipo de escuela y ubicación, ingresos por hogar, así como formación educativa de los padres mediante un cuestionario entregado a los padres. Se realizaron análisis crudos y ajustados usando regresión logística. La prevalencia de víctimas de bullying $y$ los adolescentes con sobrepeso/obesos fue de un 13,2\% y un 29\%, respectivamente. No se encontró asociación entre el bullying y la edad, sexo, tipo de escuela, educación de la madre, ingresos por hogar, y sobrepeso/obesidad. El modelo de análisis crudo de adolescentes con sobrepeso/obesos y aquellos con atributos individuales (gordo, flaco, alto, bajo, guapo, feo, procedente de un grupo étnico diferente, rico, pobre, con una discapacidad $y / u$ otros) tenían mayores probabilidades de sufrir bullying. En el análisis del modelo ajustado por ingresos por hogar, y estratificado por sexo, los chicos fueron discriminados por ser gordos, guapos, feos, o por sufrir una discapacidad, mientras que las chicas lo fueron por ser gordas, altas, bajas, feas, ricas, pobres entre otros atributos individuales.

Conducta del Adolescente; Acoso Escolar; Discriminación; Obesidad; Sobrepeso
Submitted on $12 / \mathrm{Jul} / 2017$

Final version resubmitted on 15/May/2018

Approved on 08/Jun/2018 